\title{
DADDY'S HOME: THE PROMOTION OF PATERNITY LEAVE AND FAMILY RESPONSIBILITIES IN THE SOUTH AFRICAN WORKPLACE
}

\author{
Asheelia Behari \\ LLB LLM \\ Lecturer, School of Law \\ University of KwaZulu-Natal \\ Attorney of the High Court of South Africa
}

\section{SUMMARY}

Current labour legislation provides employees with three days' family-responsibility leave for the care of their family. This means that fathers of new-born babies must rely on the provision of three days of family-responsibility leave, if they wish to take time off from work after the birth of a new baby. Alternatively, fathers will have to use annual leave on the birth of a baby. Paternity leave is exclusively offered to the working father as time off work immediately after the birth of his child, not only to care and bond with the new-born baby, but also to care for the mother during the postnatal stage. Most countries do not provide a separate legislative right to paternity leave. The right is generally included in parental-leave provisions, which provide fathers an exclusive period of leave. Providing maternity leave without a corresponding period of paternity leave creates an imbalance in family dynamics. The exclusion of paternity leave fuels the stigmatised notion of women as homemakers and caregivers. It leads to the perception that women are provided with maternity leave because the primary responsibility of women is to care for children, whereas men need not be afforded paternity leave because their primary responsibility is to be a "bread-winner". Therefore, providing the right to paternity or parental leave would promote the equal treatment and opportunities between men and women in the workplace. The Constitution guarantees gender equality and fair labour practice. South Africa has made legislative efforts to provide these rights through labour law and decisions of the Labour Court. While certain aspects of these efforts have proved effective, the labour laws of South Africa fail to provide paternity leave for fathers.

\section{INTRODUCTION}

The presence of a father at the early stages of postnatal development contributes to the maturity of the child through the bonding between father and child. ${ }^{1}$ Legal efforts to promote fatherhood would consist of efforts to provide a legislated right to paternity leave or parental leave to employees. ${ }^{2}$

\footnotetext{
Richter "The Importance of Fathering for Children" in Richter and Morrell (eds) Baba: Men and Fatherhood in South Africa (2006) 5358.

2 Morrell and Richter "Introduction" in Richter and Morrell (eds) Baba: Men and Fatherhood in South Africa 1 3; and Adams "The Family Responsibilities Convention Reconsidered: The
} 
South Africa does not provide any statutory rights for paternity leave or parental leave. Paternity leave is exclusively offered to the working father as time off work immediately after the birth of his child, not only to care and bond with the new-born baby, but also to care for the mother during the postnatal stage. Paternity leave should be inclusive of employment protection, ensuring that the father is able to return to his position of employment after the leave period. ${ }^{3}$ The leave entitlement may be offered as a separate provision or as "special leave" to which all employees are entitled. Paternity leave may be offered to employees through national legislation or collective bargaining agreements. Most countries do not provide a separate legislative right to paternity leave. The right is generally included in parental-leave provisions, which provide fathers an exclusive period of leave.

Parental leave is a gender-neutral provision which offers fathers as well as mothers the time off to care for and bond with small children. ${ }^{5}$ The leave is offered at the expiry of maternity or paternity leave. ${ }^{6}$ While the primary objective of parental leave is to promote the well-being of the child during the early stages of development, parental leave has the ancillary benefit of advocating the division of parental responsibilities between working mothers and fathers. ${ }^{7}$ Parental leave may be transferrable, or non-transferrable between parents. ${ }^{8}$ As transferrable leave, parental leave may be granted as a single leave entitlement to be shared by a parent couple. The couple is granted the right to decide which of them would use the parental leave. The parental leave may therefore be separated and taken over shorter periods of time, or at intervals, or the couple may decide to take the full duration of leave all at once. ${ }^{9}$ Alternatively, each parent may be granted a separate and individual entitlement to parental leave. This entitlement cannot be

Work-Family Intersection in International Law Thirty Years On" 2013-2014 22 Cardozo J, Int'l and Comp L 204.

3 Haas "Parental Leave and Gender Equality: Lessons from the European Union" 2003 20(1) Review of Policy Research 91; and Dancaster and Cohen "Leave for Working Fathers in the SADC Region" 201536 ILJ 2475.

4 Dancaster and Baird "Workers with Care Responsibilities: Is Work-Family Integration Adequately Addressed in South African Labour Law?" 200829 ILJ 31.

5 Haas 2003 20(1) Review of Policy Research 91; and Dancaster and Cohen "Workers with Family Responsibilities: A Comparative Analysis to Advocate for the Legal Right to Request Flexible Working Arrangements in South Africa" 2010 34(1) SALJ 28.

6 Dancaster and Cohen 201536 ILJ 2476; Dupper "Maternity Protection in South Africa: An International and Comparative Analysis (Part Two)" 2002 13(1) Stell LR 90; and Dancaster and Baird 200829 ILJ 34.

7 Field, Bagraim and Rycroft "Parental Leave Rights: Have Fathers Been Forgotten and Does It Matter?" 2012 36(2) SALR 37; and Dancaster and Cohen 201536 ILJ 2476.

8 Huysamen "Women and Maternity: Is There Truly Equality in the Workplace Between Men and Women, and Between Women Themselves?" in Malherbe and Sloth-Nielsen (eds) Labour Law into the Future: Essays in Honour of D'Arcy du Toit (2012) 46 73; and Addati "Extending Maternity Protection to All Women: Trends, Challenges and Opportunities" 2015 68(1) International Social Security Review 81; ILO www.ilo.org/maternityprotection 42-43 (accessed 2015-08-18).

9 Huysamen in Malherbe and Sloth-Nielsen (eds) Labour Law into the Future: Essays in Honour of D'Arcy du Toit 73; and Dancaster and Cohen 201536 ILJ 2481. 
transferred to the other parent. ${ }^{10}$ The family-responsibility leave offered in South Africa is insufficient to promote the care-giving role of men. ${ }^{11}$

The Constitution of the Republic of South Africa, 1996 (the Constitution) guarantees gender equality and fair labour practice. ${ }^{12}$ South Africa has made legislative efforts to provide these rights through labour legislation and decisions of the Labour Court. Both the Basic Conditions of Employment Act $(B C E A)^{13}$ and the Labour Relations Act (LRA $)^{14}$ state that their purpose is to give effect to the right to fair labour practices set out in section 23 of the Constitution, while the Employment Equity Act (EEA) ${ }^{15}$ aims to promote equal opportunity and fair treatment in employment, through the elimination of unfair discrimination. ${ }^{16}$

The right to maternity leave for female employees is provided for under the BCEA. However, without a corresponding right to paternity leave for male workers, an imbalance is created in family dynamics. The exclusion of paternity leave fuels the stigmatised notion of women as homemakers and caregivers. It leads to the perception that women are provided with maternity leave because the primary responsibility of women is to care for children, whereas men need not be afforded paternity leave because their primary responsibility is to be a "bread-winner".

There is a need to recognise fatherhood in the South African workplace, to promote the care-giving responsibilities of fathers, and in order to address the gender inequalities which exist in the workplace as a result of the limited legal regulation of postnatal childcare. Although a new-born child is dependent on maternal care for several months, the inclusion of a father as a care-giver is essential. ${ }^{18}$ The father of the family no longer fulfils the role of the sole breadwinner. He shares in the family responsibilities attached to care-giving. ${ }^{19}$ The dual role of men is not adequately recognised by the labour laws of South Africa. This is evident from the limited leave entitlements available to working fathers for the birth of a child. ${ }^{20}$ The promotion of fatherhood may encourage gender equality by easing the burden of care placed on women and creating equal obligations between women and men in terms of childcare responsibilities. ${ }^{21}$

10 Huysamen in Malherbe and Sloth-Nielsen (eds) Labour Law into the Future: Essays in Honour of D'Arcy du Toit 73.

11 Dancaster "Work-Life Balance and the Legal Right to Request Flexible Working Arrangements" 2006 2(9) SAJEMS NS 175-186; and Field et al 201236 (2) SALR 39.

$12 \mathrm{~S} 9(3)$ and $\mathrm{s} 23$ of the Constitution.

75 of 1995.

1466 of 1995.

55 of 1998.

16 S 1 (a) and (b) of the LRA; s 2(a) and (b) of the BCEA; and s 2(a) of the EEA.

Dupper 2002 13(1) Stell LR 8390.

Richter in Richter and Morrell (eds) Baba: Men and Fatherhood in South Africa 58.

19 Field et al 2012 36(2) SALR 38; and ILO www.ilo.org/maternityprotection 42-43 (accessed 2015-08-18).

20 Dancaster 2006 2(9) SAJEMS NS 175-186; and Field et al 2012 36(2) SALR 39.

21 Morrell "Fathers, Fatherhood and Masculinity in South Africa" in Richter and Morrell (eds) Baba: Men and Fatherhood in South Africa 13 18-21; Dancaster and Cohen 201536 ILJ 2474; and ILO www.ilo.org/maternityprotection 5261 (accessed 2015-08-18). 
While certain aspects of South African labour laws have proved effective, the laws do not provide enough support to employees for the effective implementation of the integration between work and family responsibilities. This article contends that the inclusion of a statutory right to paternity leave or a father-friendly right to statutory parental leave may help promote fatherhood in South Africa, and help promote equal treatment and opportunities between men and women in the South African workplace.

\section{FAMILY RESPONSIBILITY}

The BCEA provides employees with three days' family-responsibility leave which can be used by both women and men. This means that fathers of new-born babies must rely on the provision of three days of family responsibility leave, if they wish to take time off from work after the birth of a new baby. ${ }_{23}^{22}$ Alternatively, fathers will have to use annual leave on the birth of a baby.

\section{Family-responsibility leave}

Section 27 of the BCEA provides for the family-responsibility leave. Employees are entitled to three days' paid leave each year as familyresponsibility leave. It applies to those employees who have been employed for longer than four months and who work for an employer for at least four days a week. ${ }^{24}$ Section 27(2) provides that an employer must grant an employee, during each annual leave cycle, three days of paid leave, at the request of the employee. The employee is entitled to this leave when his or her child is born, when the employee's child is sick, or in the event of the death of the employee's spouse or life partner, parent, adoptive parent, grandparent, child, adopted child, grandchild or sibling. ${ }^{25}$

Family responsibility leave, as provided for under the BCEA is not a form of paternity or parental leave, and it is not exclusive to the birth or adoption of a child. ${ }^{26}$ It covers situations ranging from when a child is born or becomes sick, through to the death of a family member. ${ }^{27}$ Employees are entitled to be paid their ordinary wages for work for the days of leave and payment must be made on the usual pay day. The leave may be taken for part of the work day or an entire work day. ${ }^{28}$ The employer may require reasonable proof of the event for which the leave was required. Unused family-responsibility leave lapses at the end of the annual leave cycle in which it accrues. ${ }^{29}$ The BCEA does make provision for the variation of the

\footnotetext{
Dancaster and Cohen 2010 34(1) SALJ 3033.

Huysamen in Malherbe and Sloth-Nielsen (eds) Labour Law into the Future: Essays in Honour of D'Arcy du Toit 73.

$S 27(1)(a)$ and $(b)$ of the BCEA.

$25 \mathrm{~S} 27(2)(\mathrm{a}),(\mathrm{b})$ and (c) of the BCEA.

26 Dupper 2002 13(1) Stell LR 83 89-92; and Van Jaarsveld "Parental Leave: For the Sake of Employees and Their Children: A Comparative Study" 200214 SA Merc LJ 401.

27 Grogan Dismissal, Discrimination and Unfair Labour Practice (2005) 92-93.

$28 \mathrm{~S} 27(3)(\mathrm{a})$ and (b) of the BCEA.

29 S 27(4)-(6) of the BCEA.
} 
number of days and the circumstances under which leave is to be granted. These variations may be made by collective agreement. ${ }^{30}$

Since South African law makes no statutory provision for adoption leave, adopting parents have to rely on the provision family-responsibility leave in the BCEA. This means that an adopting parent will be entitled to only three days' leave during an annual cycle. Essentially, three days' leave to bond with a new child; settle the child into a new family and environment; and adapt to new care responsibilities cannot be considered sufficient or reasonable. ${ }^{31}$

Adoption benefits are afforded to employees through the Unemployment Insurance Act (UIA). ${ }^{32}$ According to section 27 of the UIA, only one contributor of the adopting parties is entitled to the adoption benefits in respect of each adopted child, provided that the requirements set out in the section are met. ${ }^{33}$ These requirements are that the child must have been adopted in terms of the Child Care Act; ${ }^{34}$ the period that the contributor was not working must be spent caring for the child; the adopted child must be below the age of two; and the application must be made in accordance with the provisions of the UIA. ${ }^{35}$ The contributor is entitled to the adoption benefits once the order for adoption is granted by a competent court in terms of the Child Care Act. ${ }^{36}$

Section 7(d) of the BCEA provides that every employer must regulate the working time of each employee, with due regard to the family responsibilities of employees. The Codes of Good Practice provide additional support to employees with family responsibilities, in this regard. The Code of Good Practice on the Arrangement of Working Time states that the design of shift rosters must account for their impact on "employees and their families". ${ }^{37}$ The information which is provided to the employer for the design of shift rosters must include "childcare needs of employees". ${ }^{38}$ It goes on to state that the arrangement of shift times to accommodate the special needs of pregnant and breastfeeding workers and workers with family responsibilities must be considered. ${ }^{39}$

The Code of Good Practice on the Integration of Employment Equity into Human Resource Policies and Practices, states that, with regard to workplace policies and practices, employers should provide "an accessible, supportive and flexible environment for employees with family

$30 \mathrm{~S} 27(7)$ of the BCEA states that "A collective agreement may vary the number of days and the circumstances under which leave is to be granted in terms of this section".

31 Huysamen in Malherbe and Sloth-Nielsen (eds) Labour Law into the Future: Essays in Honour of D'Arcy du Toit 66-67.

3263 of 2001 (as amended by the Unemployment Insurance Amendment Act 32 of 2003); and Field et al 2012 36(2) SALR 34.

S 27(1) of the UIA.

74 of 1983.

S 27(1)(a)-(d) of the UIA.

S 27(2) of the UIA.

Item 4.1 of the Code of Good Practice.

Item 4.2.6.

Item 5.6. 
responsibilities". ${ }^{40}$ Such an environment includes the consideration of flexible working hours and the granting of sufficient family-responsibility leave for both parents. ${ }^{41}$ Although these provisions oblige the employer to accommodate the family responsibilities of employees, Codes of Good Practice are non-binding and act only as guidelines for employers. ${ }^{42}$

\section{Family responsibilities and non-discrimination}

Section 187(1)(f) of the LRA states that a dismissal is automatically unfair if an employer unfairly discriminates against an employee on grounds which include family responsibility. Section 6(1) of the EEA provides that no person may unfairly discriminate, directly or indirectly, against any employee in any employment policy or practice, on grounds which include family responsibility. The EEA defines "family responsibilities" as the "responsibility of employees in relation to their spouse, partner, dependent children or members of their immediate family that need their care or support". ${ }^{43}$ This provision protects not only employees, but also job applicants. ${ }^{44}$ The laws which prohibit discrimination on the grounds of family responsibilities are vital because they ensure that employees who request or take time off to care for their families are secure and protected in their employment. ${ }^{45}$

Section 6(1) of the EEA protects against both direct and indirect discrimination on the grounds of family responsibilities. An employee would face direct discrimination on the grounds of family responsibilities if the employee was dismissed, or faced other prejudicial treatment by the employer due to that employee's family responsibilities, or if the employee was not promoted on the basis of an assumption that his or her family responsibilities would inhibit the employee's job performance. ${ }^{46}$ Indirect discrimination on the grounds of family responsibilities may occur where an employer practises differential treatment between employees who request flexible working hours due to family responsibilities, as opposed to those who work inflexible hours and overtime. ${ }^{47}$

\footnotetext{
Item 4.2.6 of the Code of Good Practice.

Ibid.

Ibid.

S 1 of the EEA; Cohen and Dancaster "Family Responsibility Discrimination Litigation - A Non-Starter?" 2009 20(2) Stell LR 223.

44 S 9 of the EEA. Grogan Dismissal, Discrimination and Unfair Labour Practice 104 explains that the meaning of "applicant for employment" set out in s 9 of the EEA has not yet been judicially interpreted.

45 Dancaster and Baird 200829 ILJ 2528.

46 Cohen and Dancaster 2009 20(2) Stell LR 223.

47 Ibid.
} 


\section{Case law}

\section{Co-operative Workers Association $v$ Petroleum Oil and Gas Co-operative SA}

In the case of Co-operative Workers Association v Petroleum Oil and Gas Co-operative $S A^{48}$ a group of employees claimed that their employer discriminated against them on the basis of family responsibilities by affording them a smaller contribution of medical-aid benefits from the employer than those employees with more dependants. The group of employees who brought the matter before the Labour Court claimed, on the principle of equal work for equal pay, that they were differentiated amongst the other employees, and afforded fewer benefits from the employer's contribution because of their absence of family responsibilities. Their claim rested on the grounds of unfair discrimination in terms of section 6(1) of the EEA.

The court held that the wording of section 6(1) indicated that only employees with dependants could rely on the provision. The court relied on international standards to indicate the significance of recognising "workers with family responsibilities as a vulnerable category of people deserving special treatment". ${ }^{49}$ Within the context of the case, the Labour Court held further that the special measures applied to employees with family responsibilities are a justified adjustment for the hardships of having family responsibilities. Without such adjustment, equality in the workplace cannot be attained. ${ }^{50}$ It was held that the differential treatment, based on the number of dependants of the employee, was justified because employees with greater family responsibilities require greater means to meet their responsibilities. ${ }^{51}$ The claim was dismissed.

Significantly, since the enactment of the EEA, no cases on family responsibility discrimination have been heard by the labour courts. ${ }^{52}$ The Cooperative Workers Association case was based on the differentiation between employees with family responsibilities and those without family responsibilities, and for this reason the right to not be discriminated against on the ground of family responsibilities was considered. ${ }^{53}$ The provisions of the EEA are not being used for preventing discrimination on the ground of family responsibility. A reason for the absence of cases, based on family responsibility-discrimination claims in the labour courts, may be that the onus remains on the employee wishing to rely on such a claim to initiate and fund the litigation against the employer in an individual capacity, and would then have the evidentiary burden of proving the discrimination to the court. ${ }^{54}$

\footnotetext{
(2007) 28 ILJ 627 (LC), hereinafter "Co-operative Workers Association".

Co-operative Worker Association par 42.

Co-operative Worker Association par 50.

Grogan Workplace Law (2014) 219.

Cohen and Dancaster 2009 20(2) Stell LR 227; and Dancaster and Cohen 2010 34(1) SALJ 34.

53 Co-operative Worker Association par 20, 28, 30, 36 and 52; Grogan Workplace Law 219; and Cohen and Dancaster 2009 20(2) Stell LR 227.

54 Cohen and Dancaster 2009 20(2) Stell LR 238; and Dancaster and Cohen 2010 34(1) SALJ 34.
} 


\section{MIA v State Information Technology Agency (Pty) $L t d$}

In the landmark decision of MIA $v$ State Information Technology Agency (Pty) $L t d,{ }^{55}$ the Labour Court award "maternity" leave to a male employee due to the absence of available leave entitlements for the birth of a baby born out of a surrogacy agreement. ${ }^{56}$ The employee was a partner to a civil union in accordance with the Civil Union Act. ${ }^{57}$ The couple were expecting a baby through surrogacy. The surrogacy agreement had been concluded in terms of the Children's Act 38 of 2005 and confirmed by court order. In terms of the agreement the surrogate would hand over the child to the commissioning parents at birth, who would from that time onwards be deemed to be the parents of the child and responsible for the child.

The employer's employment policies offered paid maternity leave for a period of four months to the biological mother, and paid maternity leave of two months to a permanent employee who is the adoptive mother of a child below the age of 24 months. ${ }^{58}$ In order to secure time off from work to care for his new-born baby, the employee had applied to his employer for paid "maternity" leave from the date of confinement for a period of four months. The employer refused the application on the grounds that the maternity leave offered in the policy applied exclusively to female employees. ${ }^{59}$

The employment policy failed to provide leave to parents expecting a baby through surrogacy. While the employer initially offered the employee "familyresponsibility leave", or special unpaid leave, he subsequently granted the employee two months' paid adoption leave and two months' unpaid leave. The employee applied to the CCMA to be granted paid maternity leave on the basis of unfair discrimination. He claimed that the employer refused the leave application on the basis that he was not the biological "mother" of his child, which effectively constituted unfair discrimination on the grounds of sex, family responsibility and sexual orientation, in terms of section 6(1) of the EEA.

The employer contended that the maternity-leave policy was not discriminatory. The argument was based on the word "maternity", which indicated that the leave was for the exclusive use of female employees with the specific objective of providing leave to employees who gave birth "based on an understanding that pregnancy and childbirth create an undeniable physiological effect that prevents biological mothers from working during portions of the pregnancy and during the post-partum period". ${ }^{60}$ The relief sought by the employee was the prevention of future discrimination against those in similar positions, and damages and payment for the unpaid leave he had resorted to accept, in order to take to care of his child. The dispute was referred to the Labour Court for determination.

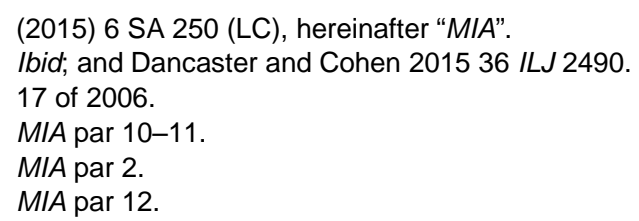


It is of particular significance in this case that the employee did not challenge the leave provisions of the BCEA, since the contention was based on the employer's maternity-leave policy. However, the court did mention that an adequate consideration of the issue would warrant instituting amendments to legislation, particularly to the BCEA. ${ }^{61}$ The decision turned on the interpretation of the right to maternity leave as set out in the BCEA. The right to maternity leave provided for in section 25 of the BCEA is only applicable to pregnant women, and not women who adopt a child, or samesex partners who conceive through a surrogacy agreement. Section 25 makes specific references to the "date of birth", from which compulsory postnatal maternity leave will begin, and provides for incidents of miscarriage, thus indicating natural birth, and not birth through surrogacy. ${ }^{62}$

Despite the exclusive wording of the section, the court found that the current objective of maternity leave set out in the BCEA, is not only intended to protect the welfare and health of the employee who gave birth, but also to account for the child's best interests. ${ }^{63}$ The court found that the right to maternity leave must be interpreted in light of the Bill of Rights in the Constitution and the Children's Act. ${ }^{64}$ Section 28 of the Constitution states that every child has the right to "family care or parental care", while section 9 of the Children's Act states that the child's best interest is of paramount importance in considering the care, protection and well-being of a child. Accordingly, these provisions command that, in matters concerning the wellbeing of a child, measures must be taken in the best interests of the child. Thus, the right to maternity leave must be interpreted so as to account the best interests of the child. ${ }^{6}$

The court noted that, since surrogacy agreements are regulated by the Children's Act, the determination of the best interests of the child in this instance depended on the terms of the surrogacy agreement. ${ }^{66}$ The surrogacy agreement specifically stated that the newborn is handed to the commissioning parents at birth, and the surrogate has no further contact with the child thereafter. For this reason the employee intended to perform the role usually performed by the birthmother in taking immediate responsibility of the child. This required the right to maternity leave. ${ }^{67}$ As such, the court found no reason why the employee should not be entitled to "maternity" leave. It stated further that there is no reason why the maternity leave should not be of the same duration as that which a natural mother would be awarded. ${ }^{68}$ The employee was awarded the "maternity leave" on the basis that it was in the best interests of the child. The court declared that the employer's maternity-leave policy constituted unfair discrimination, and ordered the employer to pay the employee an amount equivalent to two months' salary.

1 MIA par 19

62 Huysamen in Malherbe and Sloth-Nielsen (eds) Labour Law into the Future: Essays in Honour of D'Arcy du Toit 6062.

MIA par 14; and Dancaster and Cohen 201536 ILJ 2491.

38 of 2005.

65 MIA par 13-15.

MIA par 15-16.

67 MIA par 16.

68 MIA par 17. 
The case progressively accounted for the child's right to "family care or parental care"; irrespective of gender, by giving effect to the best interests of the child within the family structure of same-sex partners having conceived through surrogacy. In doing so, the case exhibited the gap in South African labour law, resulting from the failure to provide a statutory right to leave from work for the care of a child born from surrogacy. This judgment has been welcomed as a step in the right direction for workplace equality. ${ }^{69}$ It appears to break down the stereotype of women as the primary family carer, it supports a non-traditional family structure of same-sex unions, and it reflects the needs of new-born children for the care of both parents. However, the case does give rise to uncertainties and questions of practicality.

The judgment did not provide any analysis of the nature of the discrimination. Such discrimination would arise from the exclusion of surrogacy leave, or paternity leave from labour legislation that provides maternity leave to pregnant women. Rather than evaluating the argument of discrimination according to the principles of the EEA, the court based its findings on the best interests of the child. As such, the Labour Court missed the opportunity to discuss whether or not the exclusion of adequate leave provisions for fathers and surrogate parents to care for new-born children constitutes unfair discrimination. Neither did the court provide any guidelines to assist future courts or employers with leave provisions which facilitate the integration of fathers to the care of new-born children. ${ }^{7}$

This decision may be compared to the case of President of the Republic of South Africa $v$ Hugo $^{71}$ to the extent that both cases raise issues of discrimination regarding the roles of mothers and fathers in the upbringing of children. In Hugo the Presidential Act provided a special remission of sentence to certain groups of prisoners, which included all mothers with minor children under the age of 12 years, which was challenged. ${ }^{72}$ Hugo was a prisoner and a single father who sought an order declaring the Presidential Act unconstitutional on the grounds that it discriminated unfairly against him on the basis of gender. His argument was based on section 8(2) interim Constitution ${ }^{73}$, which stated that no person shall be unfairly discriminated against on the grounds of sex.

The President chose to grant the remissions to mothers with minor children on the basis that this would be in the best interests of the children. The President was motivated by the historically and socially imposed role of mothers as primary caregivers. ${ }^{74}$ The court noted that South African women are expected to carry heavy burdens of care within the labour-market circumstances of limited skill and financial resources. Women are less likely

69 Motsiri and Timothy "Sir, Your Maternity Leave has been Granted ..." 20156 HR Future 44-46.

70 Finn "Fathers Still to Go: Paternity Leave and the Labour Court's Judgment in MIA $v$ SITA" 6 April 2015 African Legal Centre http://africanlegalcentre.org/2015/04/06/farther-still-to-gopaternity-leave-and-the-labour-courts-judgment-in-mia-v-sita/ (accessed 2016-02-16).

1997 (6) BCLR 708 (CC), hereinafter "Hugo".

17 of 1994.

200 of 1993

74 Hugo 739 par 70. 
to successfully compete in the labour market. Essentially, the burden of care placed on women is a source of many gender inequalities. ${ }^{75}$

The court in the Hugo case found that the President relied on a generalisation of women's roles as primary child carers, and held that discrimination on the basis of sex did exist. However, the majority in the Constitutional Court found that, although Hugo was discriminated against on the grounds of sex, the discrimination was not unfair in the circumstances. The finding that the discrimination was not unfair was based on public policy, as well as on the facts that the male prisoners vastly outnumbered female prisoners, the prisoners' rights and obligations as fathers were not limited in any respect by the decision, and that the prisoners had no legal entitlement to an early release.

Both $M I A^{76}$ and Hugo cases have emphasised the interests of the child in examining the burden of care within a family. However, while Hugo exposed the gender stereotypes in South Africa by linking the interest of the child with the primary care of a mother, $M I A^{77}$ accounted for the child's right to "family care or parental care" irrespective of gender. In basing its decision on section 28 of the Constitution and the Children's Act, it appears that the Labour Court in the MIA ${ }^{78}$ case was attempting to support the social childcare needs of families. This means that labour legislation should reflect such objectives. As such, the three days' leave from work to care for a newborn child cannot represent the best interests of a child. The statutory rights of employees in BCEA should be extended to reflect a diverse family structure by accounting for the birth of a child through a surrogacy agreement and fathers as caregivers.

\section{INTERNATIONAL LABOUR STANDARDS}

South Africa also has numerous international obligations arising from the ratification of international policies and conventions which promote legal transformation. ${ }^{79}$ The primary international standards which support fathers with family responsibilities in the South African workplace are those of the International Labour Organisation (ILO). South Africa's international obligations regarding parental responsibilities arise from its relations with the United Nations (UN) and the African Union (AU).

The ILO Maternity and Paternity at Work: Law and Practice Across the World reviewed the national laws and practices on maternity and paternity at work in 185 countries. ${ }^{80}$ It revealed that, while various national legal systems respect maternity protection and support employees with family responsibilities, the implementation of the laws is not carried out effectively

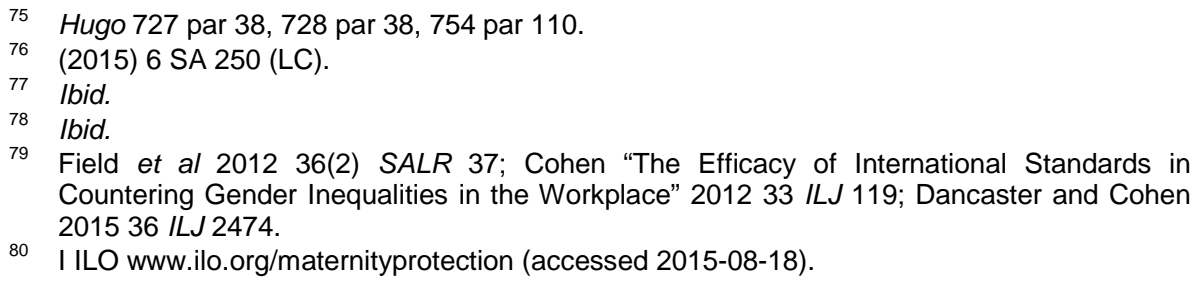


enough. ${ }^{81}$ The study calls on governments to set up and give effect to laws which encourage integration of work and family in order that family responsibilities can be equally shared between working parents. ${ }^{82}$ As a member state of the ILO, South Africa has obligations to adopt policies which further social justice and equality between men and women with regard to childcare rights, parental responsibility rights, and employmentsecurity rights. ${ }^{83}$

\section{ILO standards on paternity leave}

Although paternity leave is mentioned in the Resolution Concerning Gender Equality at the Heart of Decent Work, the ILO has not adopted any standards to provide employees with paternity leave. ${ }^{84}$ The ILO report on Maternity and Paternity at Work - Law and Practice Across the World indicated that at least 79 of 167 countries for which data were available, provide some form of paternity leave, and there has been progress on the inclusion of paternity leave in national legislation between 1994 and $2013 .{ }^{85}$ Sweden was the first country to provide paternity leave to employees with the objective of creating gender equality. ${ }^{86}$ The legislative measures of the United Kingdom (UK) provide two weeks' paid paternity leave offered by the Employment $\mathrm{Act}^{87}$ and Paternity and Adoption Leave (Amendment) Regulations, ${ }^{88}$ provided that the employee has a minimum service in the employment of 6 months. ${ }^{89}$ These regulations also make provision for adoptive parents to be afforded ordinary and additional adoption leave, maternity leave and paternity leave. ${ }^{90}$

\section{ILO standards on parental leave}

The Workers with Family Responsibilities Convention ${ }^{91}$ recognises the role of fathers with respect to family responsibilities, however, the ILO has not adopted any standards which offer paternity leave. Recommendations No. 165 and 191 mention the necessity to extend leave provisions to both mothers and fathers. The Recommendation concerning Equal Opportunities and Equal Treatment for Men and Women Workers: Workers with Family Responsibilities ${ }^{92}$ complements the Workers with Family Responsibilities Convention $^{93}$, and states that through gradual introduction of this measure

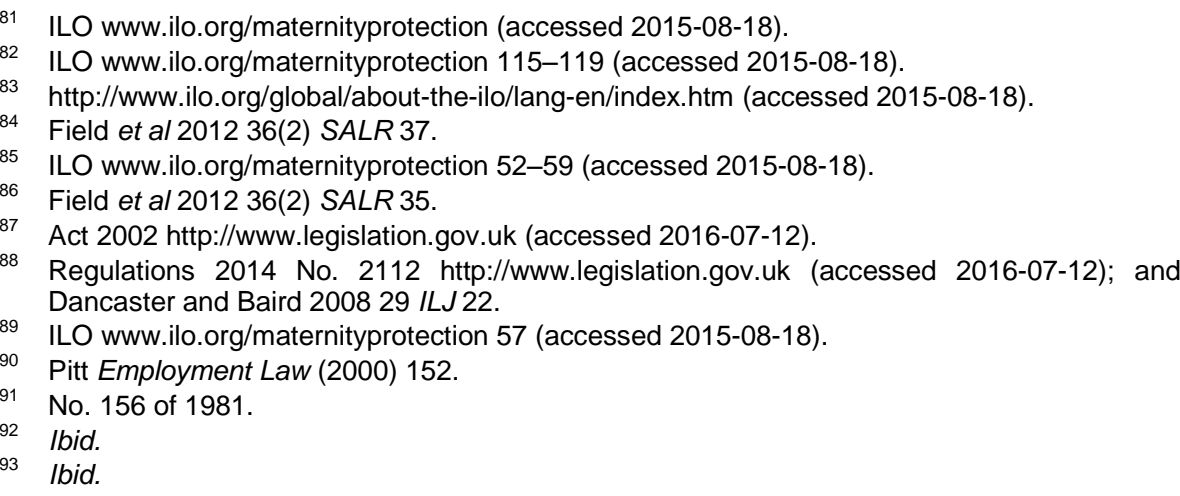


"either parent should have the possibility, within a period immediately following maternity leave, of obtaining leave of absence (parental leave), without relinquishing employment and with rights resulting from employment being safeguarded". ${ }^{94}$ The ILO report on Maternity and Paternity at WorkLaw and Practice across the World, has indicated that at least 66 of 169 countries for which data are available, provide some form of parental leave. ${ }^{95}$ For instance, according to the UK Maternity and Parental Leave, etc., Regulations, ${ }^{96}$ each parent is entitled to an independent right to thirteen weeks' unpaid leave to care for a newborn or a young child. ${ }^{97}$

Paternity and parental leave are only encouraged through ILO Recommendations which are non-binding and act as a guideline. Therefore, member states are not forced to commit themselves to the provision of paternity or parental leave. Paternity leave, or non-transferable parental leave, must be recognised as a mechanism for the promotion of equal division of family responsibilities between parents, thus influencing gender equality in the workplace. ${ }^{98}$

\section{International standards on shared parental responsibilities}

In 1979, the UN General Assembly adopted the Convention on the Elimination of All Forms of Discrimination against Women (CEDAW). ${ }^{99}$ South Africa ratified CEDAW in $1995 .{ }^{100}$ CEDAW sets out to eliminate all forms of discrimination against women with the aim to achieve gender equality, and calls for nations to take action to address such discrimination. ${ }^{101}$ According to the Preamble of the Convention, there has been a failure to fully recognise the role of both parents in the family and in the upbringing of children. ${ }^{102}$ The Preamble expressly states that the role of women in procreation should not be a basis for discrimination, but that the upbringing of children requires a sharing of responsibility between men and women and society as a whole. ${ }^{103}$ Article $16(1)(d)$ reiterates the shared responsibility of childcare between parents by stating that state parties shall ensure that men

94 Article 22(1)-(3) of the Recommendation Concerning Equal Opportunities and Equal Treatment of Men and Women Workers: Workers with Family Responsibilities No. 156 of 1981.

95 ILO www.ilo.org/maternityprotection 64 (accessed 2015-08-18).

1999 No. 3312.

97 ILO www.ilo.org/maternityprotection 64 (accessed 2015-08-18).

98 Ibid.

99 Convention on the Elimination of All forms of Discrimination Against Women http://www.un.org/womenwatch/daw/cedaw/cedaw.htm (Accessed: 2015-12-14).

100 Jansen van Rensburg and Olivier "International Law and Supra-Nation-al law" in Olivier, Smit, Kalula and Mhone Introduction to Social Security 2004619 631; Dancaster and Baird 200829 ILJ 22; and Huysamen in Malherbe and Sloth-Nielsen (eds) Labour Law into the Future: Essays in Honour of D'Arcy du Toit 54.

101 Cusack and Pusey "CEDAW and the Rights to Non-Discrimination and Equality" 201314 Melb. J Int'l L 57; Field et al 2012 36(2) SALR 38; Cohen 201233 ILJ 29.

102 Dancaster and Baird 200829 ILJ 25.

103 Preamble. Convention on the Elimination of All forms of Discrimination Against Women http://www.un.org/womenwatch/daw/cedaw/cedaw.htm (accessed 2015-12-14); Field et al 2012 36(2) SALR 37; and Dancaster and Baird 200829 ILJ 25. 
and women in family relations have the same rights and responsibilities as parents, and in all instances the best interests of the child is of paramount importance. $^{104}$

The United Nations Convention on the Rights of the Child (UNCRC) was adopted in recognition of the need to extend particular attention to children. ${ }^{105}$ South Africa ratified the Convention in 1995. ${ }^{106}$ Article 18 of the UNCRC states that efforts must be made by state parties to ensure that recognition is given to the principle that both parents have common responsibilities for the upbringing and development of the child, and that the best interests of the child will be their basic concern. ${ }^{107}$ According to these provisions state parties ensure the shared responsibility of care-giving between parents in the upbringing and development of the child. This means that fathers must be encouraged to participate in the care-giving duties, together with the mother of the child. ${ }^{108}$

The African Union is an international regional organisation which establishes minimum standards of human rights throughout Africa. ${ }^{109}$ The African Charter on the Rights and Welfare of the Child (ACRWC) is aimed at protecting the needs of the African child. ${ }^{110}$ With regard to parental responsibilities, article 20(1) of the ACRWC provides that parents, or other persons responsible for the child, shall have the primary responsibility in the upbringing and development of the child. Furthermore, the parents shall have a duty to ensure that the best interests of their child are their basic concern at all times. ${ }^{111}$ This international standard once again reinforces the importance of the inclusion of both parents in the care of children. Article $20(2)(c)$ of the ACRWC provides that state parties shall, in accordance with their means and national conditions, ensure that the children of working parents are provided with care services and facilities. The binding provisions of the CEDAW, the UNCRC and the ACRWC all encourage the shared parental responsibility of child care between the mother and the father of a household. The adoption of father-inclusive leave provisions after the birth of the child may promote the shared responsibility of child care between parents.

104 Article 16(1)(d) Convention on the Elimination of All forms of Discrimination Against Women http://www.un.org/womenwatch/daw/cedaw/cedaw.htm (accessed 2015-12-14); and Louw "The Constitutionality of a Biological Father's Recognition as a Parent" 2010 13(3) PER/PELJ 156.

105 The Convention on the Rights of the Child was adopted and opened for signature, ratification and accession by General Assembly resolution $44 / 25$ of 20 November 1989. It entered into force 2 September 1990, in accordance with article $49 \mathrm{http}: / / \mathrm{www}$.ohchr.org/ en/professionalinterest/ (accessed 2016-07-12).

106 Collection Convention on the Rights of the Child https://treaties.un.org/ (accessed 2016-0711).

107 Article 18(1) of the Convention on the Rights of the Child https://treaties.un.org/ (accessed 2016-07-11).

108 Louw 2010 13(3) PER/PELJ 156.

109 Forere and Stone "The SADC Protocol on Gender and Development: Duplication or Complementarity of the African Union Protocol on Women's Rights" 20099 African Human Rights LJ 436.

110 OAU Doc. CAB/LEG/24.9/49 (1990), entered into force Nov. 29, 1999 http://pages.au.int/ acerwc/documents/african-charter-rights-and-welfare-child-acrwc (accessed 2016-07-11).

111 Article 20(1)(a). 


\section{INTRODUCING PATERNITY LEAVE IN SOUTH AFRICA}

In October 2012, the South African Department of Social Development released the White Paper on Families (White Paper), which is aimed at promoting family well-being and socio-economic development in South Africa. ${ }^{112}$ The White Paper identifies the introduction of paternity leave as one of the recommended strategies for the promotion of a healthy family life. ${ }^{113}$ For instance, a strategy for the strengthening of the family is the introduction of paternity or parental leave in order to promote equal parenting care and responsibility between mothers and fathers, and to encourage gender equality in parenting. The White Paper relies on the Departments of Labour and Social Justice to carry out these strategies. It states that the Department of Labour must ensure that labour policies and laws support gender equality, protect workers' rights by monitoring fair practices with regard to maternity leave, and mainstream education on gender equality and work-life balance at the workplace. Lastly, and most significantly, it recommends the development and implementation of paternity leave. ${ }^{114}$ The Department of Social Justice is relied upon to explore the possibility of the inclusion of paternity leave in the BCEA, and for strengthening the recognition of parenting and support for parents at the workplace. $^{115}$

\section{CONCLUSION}

The family-responsibility leave offered in the BCEA, the Codes of Good Practice and the anti-discrimination laws (LRA and EEA) are inadequate in supporting fathers with family responsibilities. The duration of familyresponsibility leave should be increased. The eligibility for the leave should also be extended. The restriction of the leave to employees, other than those who work at least four days a week, and who have been employed for more than four months, limits the coverage by excluding numerous employees. The current labour legislation places women in the role of primary caregiver and fails to recognise the responsibilities of men as fathers. Studies have found that the greatest difference between maternal and paternal roles can be found in the division of child-care responsibilities. The more women are involved in employment, the more the division of child-care duties shift to men. However, this shift is not attributed to greater efforts made by men, but rather to the distribution of women's efforts between child-care and work. ${ }^{116}$

Laws must be adapted to reflect the shift in current family structures, where both the mother and the father are responsible for a single household, and the distribution of care-giving and housekeeping is shared between men and women, or to account for partners in a same-sex partnership who

\footnotetext{
112 Department of Social Development, Republic of South Africa: White Paper on Families in South Africa (October 2012) http://www.dsd.gov.za/index (accessed 2016-02-23).

113 White Paper on Families in South Africa 40.

114 White Paper on Families in South Africa 50-51.

115 White Paper on Families in South Africa 46.

116 Richter in Richter and Morrell (eds) Baba: Men and Fatherhood in South Africa 57.
} 
require a substantial leave of absence from work to care for their children. ${ }^{117}$ The promotion of fatherhood in the workplace through paternity leave may encourage gender equality by creating equal obligations between women and men in terms of child-care responsibilities. ${ }^{118} \mathrm{~A}$ significant contributor to gender inequality in the workplace is the unequal burden placed on women to carry out the primary role of caregiver and homemaker. ${ }^{119}$ Legal efforts to encourage the connection between fatherhood and gender equality in the workplace would include providing a statutory right to paternity or parental leave.

117 Ibid.

118 Morrell in Richter and Morrell (eds) Baba: Men and Fatherhood in South Africa 18-21.

119 Field et al 2012 36(2) SALR 30; and Dancaster and Baird 200829 ILJ 25. 